\title{
Psychosocial and economic impact of uveitis in Mexico
}

\author{
Luz E. Concha-del Río* and Rashel Cheja-Kalb \\ Inflammatory Ocular Diseases Clinic, Asociación Para Evitar la Ceguera en México, Mexico City, Mexico
}

\begin{abstract}
Objective: To determine the psychosocial and economic impact suffered by patients diagnosed with uveitis in Mexico. Methods: Survey in uveitis-diagnosed patients. Demographic data and socioeconomic level were recorded. Symptoms, time to diagnosis, type of treatment, behavior, attitudes and feelings towards the disease were identified. Results: One hundred surveys were conducted in patients with uveitis, who had a mean age of $45 \pm 17.08$ years, and socioeconomic level $\leq D$; 54 were females. Diagnostic delay was $1.87 \pm 2.73$ years. Annually, patients attend $2.1 \pm 2.14$ appointments per month, and are admitted once to the emergency department and remain hospitalized for 3.7 days. Patients use systemic treatment with steroidal anti-inflammatory drugs (53\%), immunosuppressant agents (31\%), biological therapy (7 \%), topical treatment with lubricants (44\%) or steroids (26\%) and undergo surgery (39\%). Observed comorbidities include hypertension, diabetes mellitus, rheumatoid arthritis (18\%), Sjögren's syndrome, systemic lupus erythematosus, and nonspecific chronic ulcerative colitis. Complications: visual impairment, cataracts and blindness. Uveitis affects their life in $83 \%$ of cases, in $41 \%$ does it daily, and $49 \%$ need care from another person. Seventy-nine percent receive private care and $43 \%$ have social security, with $\$ 3,590$ $\pm \$ 2,730.65$ pesos being spent monthly on medicines, transportation, medical appointments and studies. Annually, work absenteeism is $8.5 \pm 14.56$ days, plus 7.0 days of disability or hospitalization; $51 \%$ refer lack of support to learn about the disease. Conclusions: This is the first national study to portray the condition of patients with uveitis and the shortcomings they go through, including the economic and biopsychosocial fields.
\end{abstract}

KEY WORDS: Uveitis. Psychosocial impact. Economic impact.

\section{Impacto psicosocial y económico de la uveítis en México}

\section{Resumen}

Objetivo: Conocer el impacto psicosocial y económico quede la uveítis en México. Métodos: Encuesta en pacientes diagnosticados con uveítis. Se registraron datos demográficos y nivel socioeconómico. Se identificaron síntomas, tiempo al diagnóstico, tratamiento, comportamiento, actitudes y sentimientos ante la enfermedad. Resultados: Se realizaron 100 encuestas a pacientes con uveítis, con edad media de $45 \pm 17.08$ años, nivel socioeconómico $\leq D ; 54$ eran mujeres. El diagnóstico se realizó al $1.87 \pm 2.73$ años. Acuden anualmente a cita $2.1 \pm 2.14$ mes, más de 1 a urgencias y son hospitalizados 3.7 días. Utilizan tratamiento sistémico con antiinflamatorios esteroideos (53\%), inmunosupresor (31 \%), terapia biológica (7\%), tratamiento tópico con lubricantes (44\%), esteroides (26\%) y cirugías (39\%). Comorbilidades observadas: hipertensión arterial, diabetes mellitus, artritis reumatoide (18\%), síndrome de Sjögren, lupus y colitis ulcerativa crónica inespecífica. Complicaciones: deterioro visual, cataratas y ceguera. La uveítis afecta su vida en el $83 \%$ de los casos, en el $41 \%$ a diario y el 49 \% necesitan cuidados de otra persona. El $79 \%$ reciben atención privada, el $43 \%$ cuenta con seguridad social, gastando mensualmente $\$ 3,590 \pm \$ 2,730.65$ pesos en medicamentos, transporte, consulta médicas y estudios. Anualmente 
con ausentismo laboral de $8.5 \pm 14.56$ días, más 7.0 días de incapacidad u hospitalización. El 51 \% refieren falta de apoyo para conocer la enfermedad. Conclusiones: Se trata del primer estudio nacional que escenifica la condición de los pacientes con uveítis y las insuficiencias por las que atraviesan, incluyendo el ámbito económico y biopsicosocial.

PALABRAS CLAVE: Uveítis. Impacto psicosocial. Impacto económico.

\section{Introduction}

Uveitis is a group of conditions characterized by intraocular inflammation. Technically, it describes inflammation of the uvea (iris, ciliary body and choroid). Given that it can affect adjacent tissues, the term uveitis also includes inflammation of the cornea, retina, optic nerve and vitreous. ${ }^{1,2}$ It is a barely known, poorly understood and undervalued condition. ${ }^{1}$ However, it has global impact and direct relevance in several medical specialties. Worldwide, it is an important cause of vision loss at productive age, with predominance in women, and it can be the first manifestation of a systemic disease. ${ }^{1,2}$ Visual disturbances, eye discomfort, systemic diseases and drug-related adverse effects impact the quality of life and should be considered. ${ }^{1}$

Uveitis is classified according to its anatomical location as anterior, intermediate, posterior, and panuveitis. Other classifications divide it according to the type of inflammation (granulomatous and non-granulomatous) or severity or duration (acute and chronic). ${ }^{2}$

Uveitis severe forms require treatment with systemic corticosteroids, but adverse effects force the ophthalmologist to use immunosuppressive drugs. ${ }^{3-5}$

The incidence of uveitis is 20-50/100,000/year and its prevalence is $100-150 / 100,000$. However, it varies, with more infectious causes being found in less developed countries. It causes $10-15 \%$ of global blindness, ${ }^{1,2,5}$ and is the third leading cause of preventable blindness in the world. ${ }^{6}$

In addition, $25-50 \%$ of patients will have an associated systemic disease. ${ }^{2}$ There are vision-related quality of life questionnaires, which have found that visual function and general health status are poorer than in healthy people. ${ }^{2,7}$ Furthermore, poor visual acuity, ocular complications and treatment have an impact on vision-associated quality of life. ${ }^{8}$

When it occurs at productive ages, uveitis has a significant socioeconomic impact. ${ }^{6}$ This depends on many factors, including the cause and duration of the disease, comorbidities, patient/family income or government support. ${ }^{2}$ So far, there is a lack of information about the psychosocial and economic effects experienced by patients diagnosed with uveitis in Mexico.
The purpose of our study is to know this impact and identify the factors that influence on quality of life.

\section{Material and Methods}

The purpose of the study is to know the psychosocial and economic impact suffered by patients diagnosed with uveitis in Mexico. It was carried out at the Inflammatory Ocular Diseases Clinic of the Luis Sánchez Bulnes Hospital, Association to Avoid Blindness in Mexico (APEC), in October and November 2018.

\section{Participants and study design}

Interviews were conducted on people with uveitis, older than 18 years of age. First, they were given an informed consent document. After affirmative answer was obtained, the interviews were personally conducted. The questions were developed by clinicians experienced in the management of ocular inflammation, using closed (dichotomous, categorized, scale and multiple choice) and open questions. A five-module strategy was used: 1) demographic data and standardized questions designed by AMAI; b) presenting symptoms, time to diagnosis, type of treatment and follow-up; c) behavior, attitudes and feelings towards the disease; d) knowledge and sources of information, and e) unmet needs.

\section{Data analysis}

The questionnaires were coded, data were filtered, consolidated and analyzed using a computerized database. Subsequently, a thematic analysis was carried out. Relative frequencies and central tendency measures were used for descriptive variables.

\section{Results}

\section{Profile of the surveyed patient}

One hundred patients were included. Fifty-six percent of uveitis-affected individuals are women, with a mean age of $45 \pm 17.08$ years and, in $61 \%$, 
socioeconomic level is $\leq \mathrm{D}$. Places of residence include Mexico City (36\%), State of Mexico (26\%), Puebla (7\%), Guerrero (6 \%), Oaxaca (6\%), Morelos (5\%), and the rest, other States. Seventy-one percent receive medical care exclusively at the private sector, and $21 \%$, mixed care. Forty-three percent have social security, either directly or via the spouse and/or child (Table 1).

\section{Symptoms, time to diagnosis, type of used treatment and follow-up}

Main symptoms were poor vision (67\%), eye pain (60\%), eye inflammation (60\%) and headache (42\%). Disease was bilateral in $44 \%$. Diagnosis was established at $1.87 \pm 2.73$ years from symptoms onset, and $3.7 \pm 3.15$ physicians, including ophthalmologists, general practitioners, rheumatologists and nephrologists, were consulted. Patients who were promptly diagnosed reside in Mexico City and/or the State of Mexico.

Patients are currently treated at APEC, in a clinic with specialists in ocular inflammation, and attend an average of 6.3 visits per year (range, 1 to 50 ), with a frequency of every $2.1 \pm 2.14$ months; patients attend more than once the emergency department and remain hospitalized for 3.7 days due to the eye condition (Table 2).

Systemic treatment is with steroidal anti-inflammatory drugs (53\%), immunosuppressant drugs (31\%) and biological therapy (7\%). For topical treatment, lubricants (44\%) and steroids (26\%) are used. Thirty-nine percent have undergone surgery, with a mean of $1.6 \pm 1.04$ operations since diagnosis, with procedures including cataract $(21 \%)$, retina (8\%) and glaucoma surgeries (4\%) (Table 3). Main complications include significant visual impairment in $69 \%$, cataracts in $39 \%$, blindness in $34 \%$, and vitreous opacities in $28 \%$.

Most common comorbidities were hypertension and diabetes mellitus, followed by those of autoimmune origin, such as rheumatoid arthritis in $18 \%$, Sjögren's syndrome in $5 \%$, systemic lupus erythematosus $4 \%$, and chronic nonspecific ulcerative colitis (CNUC) in $3 \%$ (Table 2).

\section{Behavior, attitudes and feelings towards the disease}

Regarding inflammation severity at diagnosis, $21 \%$ considered it mild; $22 \%$, moderate; $43 \%$, severe; and
Table 1. Demographics, socioeconomic level and social security

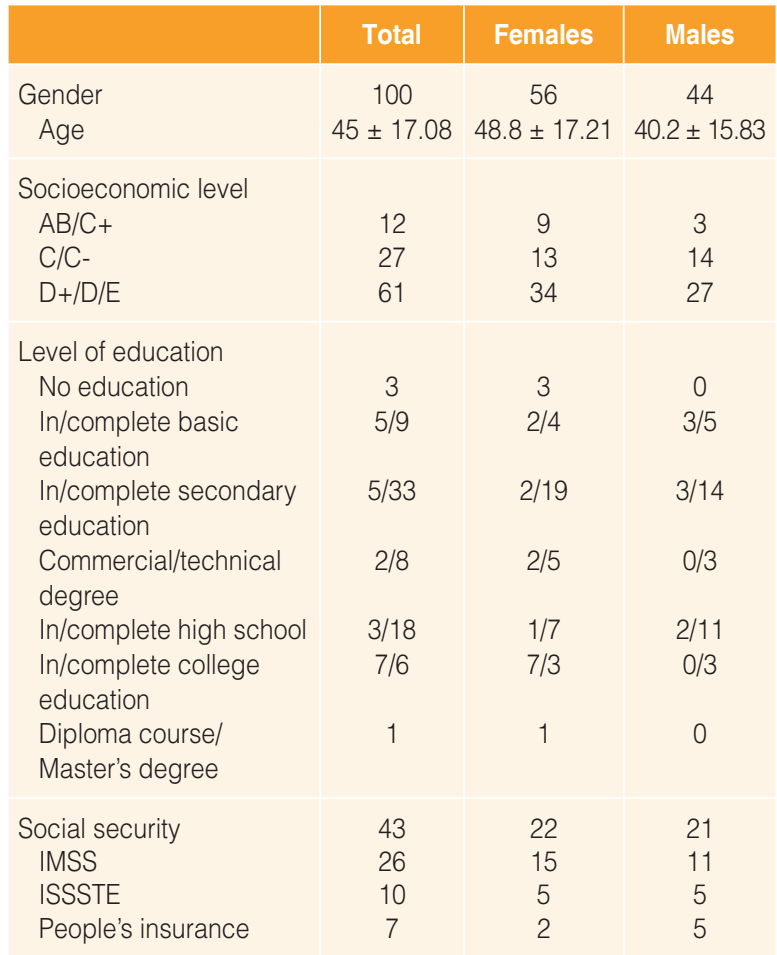

ISSSTE (Instituto de Seguridad y Servicios Sociales de los Trabajadores del Estado) = Institute of Social Security and Services for State Workers; IMSS (Instituto Mexicano del Seguro Social) $=$ Mexican Institute of Social Security.

Table 2. Previous medical care and comorbidities

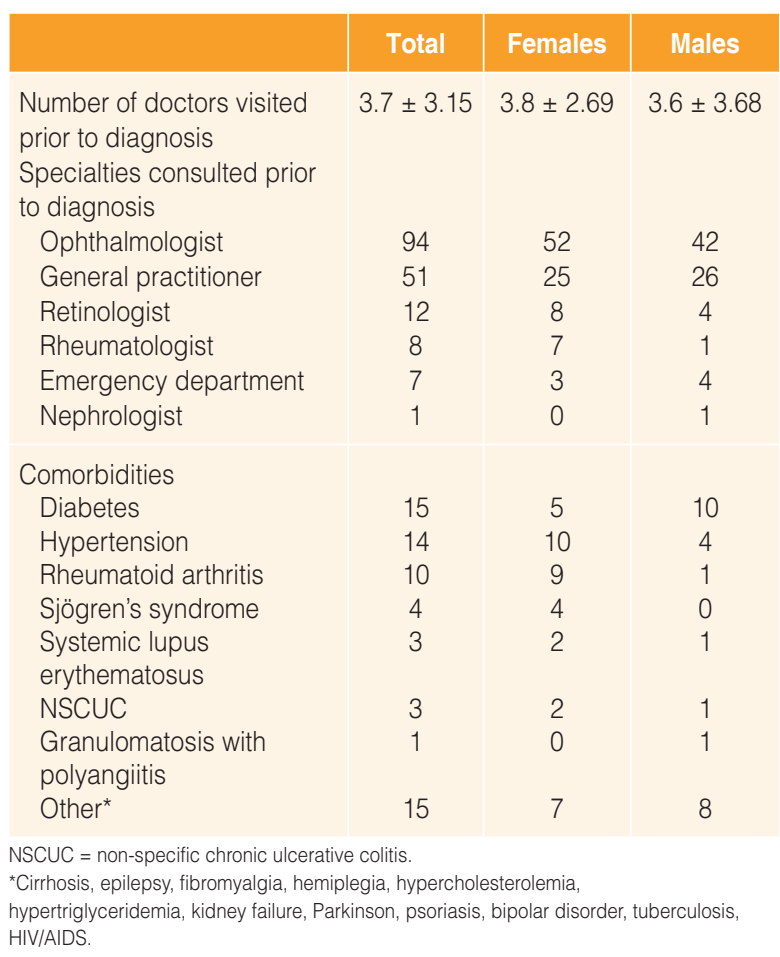

$14 \%$ did not know; and at the time of the interview, $32 \%$ changed it to mild; $24 \%$, to moderate; $14 \%$, to 
Table 3. Medical and surgical treatment

\begin{tabular}{|c|c|c|c|}
\hline & Total & Females & Males \\
\hline $\begin{array}{l}\text { Anti-inflammatory treatment } \\
\text { Oral steroids* } \\
\text { Immunosuppressant }^{\dagger} \\
\text { Biological drug } \\
\text { Alkylating agents } \\
\text { Intravitreal tramcinolone } \\
\text { Periorbital betamethasone } \\
\text { Implanted devices" } \\
\text { Oral NSAID }\end{array}$ & $\begin{array}{l}53 \\
31 \\
7 \\
3 \\
9 \\
8 \\
2 \\
2\end{array}$ & $\begin{array}{l}28 \\
11 \\
4 \\
1 \\
6 \\
4 \\
0 \\
2\end{array}$ & $\begin{array}{l}25 \\
20 \\
3 \\
2 \\
3 \\
4 \\
2 \\
0\end{array}$ \\
\hline $\begin{array}{l}\text { Anti-infectious and surgical } \\
\text { treatment } \\
\text { Oral antibiotic/antiviral } \\
\text { Surgeries } \\
\text { Surgeries since diagnosis } \\
\text { Surgeries within previous year } \\
\text { Cataracts } \\
\text { Vitrectomy } \\
\text { Ahmed glaucoma valve }\end{array}$ & $\begin{array}{c}6 \\
39 \\
1.6 \pm 1.04 \\
0.8 \pm 0.96 \\
21 \\
8 \\
4\end{array}$ & $\begin{array}{c}3 \\
20 \\
1.6 \pm 1.04 \\
1 \pm 1.19 \\
8 \\
15 \\
0\end{array}$ & $\begin{array}{c}3 \\
19 \\
1.5 \pm 0.96 \\
0.6 \pm 0.61 \\
13 \\
5 \\
4\end{array}$ \\
\hline $\begin{array}{l}\text { WSAID: non-steroidal anti-inflammatory dru } \\
\text { Prednisone, deflazacort. } \\
\text { Azathioprine, chloroquine, cyclosporine, } \\
\text { nycophenolate mofetil, sulfasalazine. } \\
\text { Adalimumab, anakinra, golimumab, inflixi } \\
\text { Cyclophosphamide. } \\
\text { Ozurdex. }\end{array}$ & oxychloroquin & methotrexa & \\
\hline
\end{tabular}

severe; and $5 \%$ did not know. As for the cause of uveitis, $31 \%$ of patients do not know it.

\section{Impact on patient daily life and costs associated with uveitis}

Life is affected by uveitis in $83 \%$ of patients, and this impact is daily in $41 \%$. Something has changed for all of them, in addition to the medical condition, including emotional, psychological, occupational, school, autonomy and social problems. Patients refer negative emotions such as helplessness, annoyance, sadness, despair, anger, fear, and frustration. In addition, $49 \%$ of patients need care from a family member, which is provided by the mother, daughter and/or wife.

Regarding the expenses generated by the disease, patients invest $\$ 3,590 \pm \$ 2,730.65$ pesos (MXP) monthly. Seventy-one percent spend between $\$ 1,001$ and $\$ 5,000$ pesos monthly, mainly in medicines, transportation, medical appointments and tests.

Regarding the job situation, $21 \%$ have formal employment; with absences for attending medical appointments of $8.5 \pm 14.56$ days per year and for disability or hospitalization, 7.0 days per year (Table 4).

\section{Knowledge and sources of information}

Patients obtain information about the disease from the specialist physician (62\%), the internet (44\%), the hospital $(23 \%)$, social networks (8\%), relatives (8\%) and books (7\%).

\section{Unmet needs}

Lack of support to learn about the disease is reported by $51 \%$ of patients, and $76 \%$ are willing to join a support association. They request psychological support $(63 \%)$, support materials (53\%), a place to meet with people in the same situation (45\%), rapid access to a medical appointment with a specialist (45\%), a call center for solving doubts (39\%), a trustworthy website (31\%), financial support (16\%) and support for medication (6\%) (Table 5).

\section{Discussion}

The importance of the study lies in that it allows the perspective of the patient with inflammatory eye diseases in our country to be known. The results of the survey show the impact on the lives of those affected. Since the onset of the disease, the patient experiences a delay in diagnosis, and an impact on affective, emotional, social and economic aspects. ${ }^{9,10}$

Patients report that uveitis affects their life by $83 \%$, and $41 \%$, every day, mainly emotionally and at work, and almost half of them require help from relatives. One of the main concerns is the effect of vision loss on quality of life..$^{10}$

Another point to be taken into account is that patients are young, with a mean age of 45 years, they attend six medical appointments a year, they visit the emergency room, have absenteeism from work and remain hospitalized. Similar annual situations are described in the USA, ${ }^{11}$ or up to 11 medical appointments per year, ${ }^{12}$ and $51.2 \%$ visit the emergency department at least once a year. ${ }^{6}$

The estimated economic impact of visual loss in patients younger than 40 years is higher than $\$ 38$ billion USD, due to medical care, patient support, and quality of life loss. ${ }^{12}$ Almost one quarter of patients are unemployed, and that is related to poor vision, multiple medical appointments and hospitalizations; this is consistent, since patients are unable to maintain their employment while being treated.12 
Table 4. Monthly expenses and occupational status

\begin{tabular}{|c|c|c|c|}
\hline & Total & Females & Males \\
\hline $\begin{array}{l}\text { Uveitis-associated monthly expenditure } \\
\quad<\$ 1,000 / \text { month } \\
\$ 1,0001 \text { to } \$ 5,000 / \text { month } \\
\$ 5,001 \text { to } \$ 10,000 / \text { month } \\
>\$ 10,001 / \text { month }\end{array}$ & $\begin{array}{c}3,590 \pm 2,730.65 \\
8 \\
71 \\
17 \\
4\end{array}$ & $\begin{array}{c}3,571.4 \pm 2,715.99 \\
5 \\
39 \\
10 \\
2\end{array}$ & $\begin{array}{c}3,613.6 \pm 2,780.46 \\
7 \\
32 \\
16 \\
2\end{array}$ \\
\hline $\begin{array}{l}\text { Expenditure areas } \\
\text { Medicines } \\
\text { Transportation } \\
\text { Medical appointments } \\
\text { Investigations/tests } \\
\text { Glasses } \\
\text { Emergency department visits } \\
\text { Surgeries } \\
\text { Disposable products } \\
\text { Accommodation/lodging }\end{array}$ & $\begin{array}{l}92 \\
70 \\
47 \\
43 \\
33 \\
18 \\
11 \\
7 \\
1\end{array}$ & $\begin{array}{c}51 \\
39 \\
27 \\
22 \\
19 \\
9 \\
5 \\
3 \\
1\end{array}$ & $\begin{array}{c}41 \\
31 \\
20 \\
1 \\
14 \\
9 \\
6 \\
4 \\
0\end{array}$ \\
\hline $\begin{array}{l}\text { Current occupational situation } \\
\text { Unemployment } \\
\text { Formal employment } \\
\text { Informal job } \\
\text { Homemaker } \\
\text { Student } \\
\text { Retired } \\
\text { Day laborer } \\
\text { Pensioner } \\
\text { Disabled }\end{array}$ & $\begin{array}{c}23 \\
21 \\
16 \\
15 \\
10 \\
6 \\
5 \\
3 \\
1\end{array}$ & $\begin{array}{c}14 \\
8 \\
10 \\
14 \\
4 \\
4 \\
0 \\
2 \\
0\end{array}$ & $\begin{array}{c}9 \\
13 \\
6 \\
1 \\
6 \\
2 \\
5 \\
1 \\
1\end{array}$ \\
\hline $\begin{array}{l}\text { Absenteeism due to medical appointments (year) } \\
\text { Hospitalization days (year) }\end{array}$ & $\begin{array}{l}8.5 \pm 14.56 \\
3.7 \pm 4.32\end{array}$ & $\begin{array}{l}7.7 \pm 6.41 \\
3.5 \pm 5.08\end{array}$ & $\begin{array}{l}9.3 \pm 19.59 \\
3.8 \pm 3.73\end{array}$ \\
\hline
\end{tabular}

Table 5. Psychological aspects influenced by uveitis

\begin{tabular}{|l|c|c|c|}
\hline & Total & Females & Males \\
\hline Emotional/psychological & 54 & 31 & 23 \\
\hline Work-related & 50 & 27 & 23 \\
\hline Care dependency & 49 & 24 & 25 \\
\hline Mobility & 41 & 27 & 14 \\
\hline Autonomy/disability & 32 & 19 & 13 \\
\hline Social relationships & 24 & 11 & 13 \\
\hline Discrimination & 17 & 9 & 8 \\
\hline None & 17 & 11 & 14 \\
\hline Finding a partner & 4 & 1 & 3 \\
\hline School-related & 2 & 0 & 2 \\
\hline Limitation when using a computer & 1 & 0 & 1 \\
\hline Impaired memory & 1 & 1 & 0 \\
\hline
\end{tabular}

The time to reach diagnosis is more than one year, and patients resort to an average of $3.7 \pm 3.15$ doctors to be diagnosed, including ophthalmologists and other specialists. Other studies report diagnosing $81.2 \%$ in a subsequent appointment, although we do not know after how many. ${ }^{12}$ Uveitis timely diagnosis reduces the risk of complications that contribute to economic burden, disability and disrupt the psychosocial sphere. ${ }^{13}$
Patients spend $\$ 3,590 \pm \$ 2,730.65$ pesos monthly on their disease. APEC is a hospital that belongs to the board of Private Assistance Institutions and is a referral hospital. Patients come from various States, with $62 \%$ being from the metropolitan area, followed by Puebla, Guerrero and Oaxaca. Patient consultation cost at the time of the study was $\$ 180$ pesos; the patient also pays for laboratory and imaging investigations, surgeries and medications, even when $43 \%$ of the patients have social security, which is a lower figure than that reported in Mexico in 2018 (63.9\%). 14-16 Patients spend more on medicines and transportation, similar to expenditure for glaucoma. ${ }^{17}$ In Spain and France, the highest expenses are for hospitalizations and medications. ${ }^{18,19}$

As for complications, cataracts were found in $39 \%$ of patients; other studies report them in up to $77.3 \% .{ }^{20}$ We do not know the number of patients with glaucoma, but if we assume the numbers, it would reach figures as high as $20 \% .{ }^{21}$ Blindness was reported in $34 \%$, but it is the patient perception and we do not know if reports correspond to legal blindness (5-29\%). ${ }^{9,21,22}$ Blindness is also associated with other 
expenses, such as those generated by depression (39\%), use of optical devices (33\%), residential care (30\%) and visual rehabilitation (11\%). ${ }^{23}$

Patients with uveitis have chronic degenerative comorbidities, mainly diabetes mellitus (5.7-27.2 \%) and hypertension (15.6-29.3\%), which represent an extra expense. ${ }^{20-25}$ We found diabetes in $17 \%$, which is higher than that reported for Mexico, which is $9.4 \%,{ }^{26}$ and hypertension in $20 \%$, which is lower than reported. ${ }^{26}$

In addition, one third have autoimmune diseases, mainly rheumatoid arthritis (17 \%), followed by Sjögren's syndrome, lupus and nonspecific chronic ulcerative colitis (NSCUC), which is consistent with described observations. , $^{9,20}$

Patients with non-infectious uveitis have more autoimmune, serious diseases, require hospitalization and use of immunosuppressive and/or biological agents, which account for $20 \%$ of health costs. There are country-specific treatment guidelines and expenses vary. ${ }^{22}$ Our patients use oral steroids (53\%), immunosuppressant drugs (34\%), and biological therapy (7\%), in comparison with the US, where biological therapy (40\%), oral steroids (33.0\%) and immunosuppressant drugs (15.3\%) are used. ${ }^{6,23}$ Long-term treatments with immunosuppressant agents are used to prevent blindness, ${ }^{23}$ but this negatively influences on general quality of life scores..$^{10,27}$

Half the patients want information about the disease and psychological or financial support. Seventy-six percent want to belong to a support association. An informed patient is a better patient, for understanding the diagnosis, making decisions and having better treatment adherence, thus improving well-being and mortality. Patient level of education positively influences on interpretation of indications and negatively on having poorer health outcomes, which increases hospitalizations and visits to the emergency room. ${ }^{28}$ Therefore, quality educational material should be developed. ${ }^{28}$

This is the first Mexican study on the impact and cost of uveitis. Limitations include that only patient perception is considered, without a validated questionnaire being used, and the methodological approach lacks quantitative research rigor. In uveitis, there is little qualitative research that uses quality of life measures to improve patient care. ${ }^{29}$ It should be taken into account that patient word influences health policy, affects the provision of treatment, helps us improve management and research because patients' comments are included. ${ }^{29}$
The survey provided us with objective information from the psychosocial field and subjective data on patient attitudes and opinions. The weak point is that ophthalmological diagnoses, complications and disease severity depend on patient perception, and thus the impact and cost of the disease will have to be validated with studies and other estimations.

\section{Conclusions}

In our medical practice we have to pay attention to patients' voice in order to know what they are experiencing with regard to their disease, and what their priorities and needs are. This study depicts the situation of patients with uveitis and the shortcomings they go through. The economic burden associated with uveitis is significant to the patient, his/her family, and the health system. In addition, changes are generated in patient biopsychosocial milieu. It is important to establish an early diagnosis, provide adequate treatment, prevent progression and thus reduce visual loss.

\section{Conflict of interests}

There are no conflicts of interest.

\section{Funding}

Patient surveys were conducted by Ipsos.

\section{Ethical disclosures}

Protection of human and animal subjects. The authors declare that no experiments were performed on humans or animals for this research.

Confidentiality of data. The authors declare that they have followed the protocols of their work center on the publication of patient data.

Right to privacy and informed consent. The authors have obtained informed consent from the patients and/or subjects referred to in the article.

\section{References}

1. Krishna U, Ajanaku D, Denniston AK, Gkika T. Uveitis: a sight-threatening disease which can impact all systems. Postgrad Med J. 2017;93(1106):766-73

2. Durrani OM, Meads CA, Murraya PI. Uveitis: a potentially blinding disease. Ophthalmologica. 2004;218(4):223-36

3. Miserocchi E, Modorati G, Mosconi P, Colucci A, Bandello F. Quality of life in patients with uveitis on chronic systemic immunosuppressive treatment. Ocul Immunol Inflamm. 2010;18(4):297-304.

4. Kaleemunnisha S, Sudharshan S, Biswas J. Quality of life in non-infectious uveitis patients on immunosuppressive therapy. Middle East Afr J Ophthalmol. 2014;21(3):225-31. 
5. Gui W, Dombrow M, Marcus I, Stowe MH, Tessier-Sherman B, Yang E, et al. Quality of life in patients with noninfectious uveitis treated with or without systemic anti-inflammatory therapy. Ocul Immunol Inflamm. 2015;23(2):135-43.

6. Nelson WW, Rice JB, White AG, Johnson M, Reiff J, Lima AF, et al. Predictors of high-cost patients with noninfectious inflammatory eye diseases. ClinTher. 2019;41(11):2331-42.

7. Hui MM, Wakefield D, Patel I, Cvejic E, McCluskey PJ, Chang JH. Visual functioning and health-related quality-of-life are compromised in patients with uveitis. Ocul Immunol Inflamm. 2017;25(4):486-91.

8. Missaka RFBG, Souto FMS, Albornoz NCA, Gaspar Carvalho da Silva FTB, Lavezzo MM, Oyamada MK, et al. Self-reported quality of life in patients with long-standing Vogt-Koyanag-Harada disease. Ocul Immunol Inflamm. 2019;28:1-12.

9. Fernández-Ortega MA. El impacto de la enfermedad en la familia. Rev Fac Med UNAM. 2004:47(6):251-4

10. Haasnoot AJW, Sint Jago NFM, Tekstra J, de Boer JH. Impact of uveitis on quality of life in adult patients with juvenile idiopathic arthritis. Arthritis Care Res. 2017:69(12):1895-902.

11. Thorne J, Tundia N, Skup M, Macaulay D, Revol C, Chao J, et al. Healthcare resource use and costs in persistent nonlanterior nonainfectious uveitis. Acta Opthalmol. 2014:92(s253).

12. Bajwa A, LeeCS, Patrie J, Xin W, Reddy AK. Clinical and visual outcomes of patients with uveitis in the mid-Atlantic United States. Clin Opthalmol. 2015;8:1555-64.

13. Rodriguez Gonzáles MA, Ramírez Aranda JM, de los Santos Reséndiz H, Lara Duarte MY, Pazaran Zanella SO, Méndez López JF, et al. Health care utilization of Mexican patients with medically unexplained physical symptoms. Colomb Med. 2016:47(3):155-9.

14. IMSS. Estadísticas e informes [Internet]. Gobierno de México, Instituto Mexicano del Seguro Social [accessed Feb 11, 2020]. Available at: http:// www.imss.gob.mx/imss-bienestar/estadisticas

15. IMSS. Anuarios estadísticos [Internet]. Gobierno de México, Instituto Mexicano del Seguro Social [accessed Feb 11, 2020]. Available at: https://www.gob.mx/issste/documentos/anuarios-estadisticos

16. Sistema de protección Social en Salud. Informe de resultados enero-diciembre 2018 [Internet]. Gobierno de México, Secretaría de Salud, Seguro Popular [accessed Feb 11, 2020]. Available at: http://www.transparencia.seguro-popular.gob.mx/contenidos/archivos/transparencia/ planesprogramaseinformes/informes/2018/IR \%20Integrado \%20 (25-01-2019).v.final.pdf

17. Lazcano-Gomez G, Ramos-Cadena ML, Torres-Tamayo M, Hernández de Oteyza A, Turati-Acosta M, Jiménez-Román J. Cost of glaucoma treatment in a developing country over a 5-year period. Medicine. 2016;95(47):e5341.

18. Kobelt G, Richard B, Plesnilla C, Buchholz P, Brezin A, Heron E, Labetoulle M, Sahel J, Bodaghi B. Evaluation of the Cost of Uveitis Treatment:One Year Analysis From a Retrospective Chart Review in France. Invest. Ophthalmol. Vis. Sci. 2008;49(13):4985.

19. Adán-Civera AM, Benítez-del-Castillo JM, Blanco-Alonso R, Pato-Cour E, Sellas-Fernández A, Bañares-Cañizares A. Carga y costes directos de la uveítis no infecciosa en España. Reumatol Clin. 2015;12(4):196-200.

20. Multicenter Uveitis Steroid Treatment (MUST) Trail Follow-up Study Research Group. Quality of life and risks associated with systemic anti-inflammatory therapy versus fluocinolone acetonide intraocular implant for intermediate uveitis, posterior uveitis, or panuveitis. Fifty-four-month result of the multicenter uveitis steroid treatment Trial and follow-up study. Ophthalmology. 2015;122(10):1976-86.

21. Dick A, Tundia N, Sorg R, Zhao C, Chao J, Joshi A, et al. Risk of ocular complications in patients with noninfectious intermediate uveitis, posterior uveitis, or panuveitis. Ophthalmology. 2016;123(3):655-62.

22. Rothova A, Suttorp-van Schulten MS, Frits Treffers W, Kijlstra A. Causes and frequency of blindness in patients with intraocular inflammatory disease. Br J Ophtalmol. 1996;80(4):332-6.

23. Singh DK, Magrey M. Racial differences in clinical features and co-morbidities in ankylosing spondylitis in the United States. J Rheumatol. 2020;47(6):835-8.

24. Squires H, Poku E, Bermejo I, Cooper K, Stevens J, Hamilton J, et al. A systematic review and economic evaluation of adalimumab and dexamethasone for treating non-infectious intermediate uveitis, posterior uveitis or panuveitis in adults. Health Technol Assess. 2017;21(68):1-170.

25. Chi CC, Tung TH, Wang J, Lin YS, Chen YF, Hsu TK, et al. Risk of uveitis among people with psoriasis a nationwide cohort study. JAMA Ophthalmol. 2017;135(5):415-22.

26. Bello-Chavolla OY, Rojas-Martinez R, Aguilar-Salinas CA, Hernández-Avila M. Epidemiology of diabetes mellitus in Mexico. Nutr Rev. 2017;75(1):4-12.

27. Tan P, Koh YT, Wong PY, Teoh SC. Evaluation of the impact of uveitis on visual-related quality of life. Ocul Immunol Inflamm. 2012;20(6):453-9.

28. Navarro Rubio MD, Gálvez Hernández P, González de Paz L, Virumbrales Cancio M, Borrás Santos A, Santesmases Masana R, et al. Desarrollo de materiales educativos para pacientes crónicos y familiares. Educ Med. 2019:20(6):341-6.

29. Dean S, Mathers JM, Calvert M, Kyte DK, Conroy D, Folkard A, et al. "The patient is speaking": discovering the patient voice in ophthalmology. Br J Ophthalmol. 2017;101:700-8. 